\title{
Christmas Echoes and Reminiscences
}

\author{
By Mrs. R. A. PoAge
}

As an Iowa product, any reminiscences that I bring must of necessity have an Iowa flavor. Born within a few miles of the exact center of the state, having lived in that same rural community almost my entire life, and not yet very far from that locality, I shall digress only a little to speak of "Then and Now." My education began in one of those little white school houses, so well known to Iowans, and when I had reached the top of the curriculum there, I went to a very good little Academy known as the Hazel Dell Academy in the town of Newton.

In that academy there were no set courses of study. Each student chose from the long list of subjects offered such texts as he felt best suited his needs, and so it happened that I took what would now correspond to a very good high school course. The one subject I wish to mention, however, is astronomy. Nowadays no one who is not intending to specialize takes astronomy, but we loved it and there was quite a large class of us. I think the reason for this was that in those days we saw the stars.

Ninety-five percent of those academy students were boys and girls from the farm and all such persons spent a great deal of time out under the stars. Whenever we went anywhere after dark, we traveled by the natural night lights. All transportation was slow and no vehicle, with the exception of the single seated top buggy, had any top whatever. Hence, we rode for hours under the starry skies, and many times I remember as we rode along, perhaps in a bobsled full of young people, some one of us would recite "The heavens declare the glory of God and the firmament showeth his handiwork," etc.

Those of us who knew where to look for them could pick out the several planets visible to the naked eye; 
we knew whether Jupiter or Venus was the evening star, traced the milky way in all of its soft beauty, the Little Dipper, the Big Dipper, the Great Bear and other constellations. Yes, we loved the stars and we really saw them. Now, everywhere, all over the county, all the cities and towns are brilliantly lighted with electric lights, the farmsteads too have their outside lights. Then, too, there now are the auto lights and the airplane lights, all of which reflect against dust particles in the air, put out the stars to a certain extent and no one now really sees a starry sky in its full beauty.

And, along about Christmas, they were so beautiful. They seemed to come down so much closer and sparkle more vividly. The Christmas story of the shepherds "abiding in the fields keeping watch over their flocks of sheep by night," the stable with its suggestion of other domestic animals, the manger and the sweet smelling hay, with the Babe thereon, all were very real, very close to the life of the child who lived on the farm. Then, the wonderful Star that came out of the East, made the Christmas story a living truth easily understood and loved.

\section{Clothes and Position Counted}

As I thought over the months and years I spent at that academy, the principal difference noted was the fact that social lines were more sharply drawn than they are now. Those were the days of ostentation, showing off, snobbery and "dudeism." New York had its "four hundred," the entrance to which depended on family antecedents and money. Boston's top circle was decided more on cultural lines. But, every city and town copied, imitated and patterned after the doings of these so-called socialites. So it happened that in the little town of Newton like elsewhere there was a group who considered themselves the "elite." The young people of the town naturally aped the adults and so we soon found that the location of your birth in some way made a difference. You have all heard of being "born on the wrong side of the tracks," and as I have already 
stated, ninety-five percent or more of the students attending that academy were from the farm; therefore we heard, and bitterly resented, such appellations as "Country Greenhorn," "Country Jake," "Clod Hopper" or "Pumpkin Husker."

Our next door neighbor on the farm was a German family, and one of their daughters worked for some time as a maid in the home of one of the recognized social leaders in the town. She told us that Mrs. Csaid that she could "smell a farmer across a forty-acre field and a mechanic through a ten-foot wall," so you see being one of the "elite" improved the olfactories even if it did not improve the manners.

I was always conscious that often our outward appearance was of necessity somewhat different. No matter how carefully we groomed ourselves before we left home, by the time we had reached our destination, traveling as we must, we arrived somewhat windblown, wrinkled, with perhaps a layer of either dust or mud spatters, depending on the weather. No matter how dexterous your escort was in assisting you to alight from the vehicle, you seldom avoided some slight deposit of one or the other. And so you could not appear as immaculate as your city sister, who had stepped out of her boudoir and walked a few blocks. I remember one weekend, when there were five of us from our country school district attending the academy, and we always came and went together, that all the way along going home we pretended that we had absorbed the city culture, or lack of culture, and that we had become "citified" and when we saw a farmer out at his evening chores, remarked on that fact that there was a "Clod Hopper" and we wondered if he had "husked his pumpkins," playing a foolish game of pretense and amusing ourselves.

But now, no young person is ostracized because of his father's occupation, providing it is an honest and honorable one, and all of these town people are crowding out trying to get as close as possible to the good old mother earth. 


\section{Not A Commercial Event}

In my early childhood, Christmas was not commercialized as it is now. It seems wrong to make so beautiful a religious anniversary a money-making event. The fact that the Wisemen brought gifts to the Babe should not have been a basis for the extent to which it has become a gift exchange, so elaborate, so extensive as to be in some cases burdensome.

It was not until I was a grown girl that the stores began advertising articles as suitable for gifts and not until 1890 did any stores in Iowa put in window displays for Christmas. As a small child, I never expected much. Of course, we hung up our stockings and in the morning, in them would be a big red apple or an orange, some sticks of striped candy or perhaps a doughnut or animal cookies and one small gift. It might be a homemade dolly from mother's scrap bag or a pair of knitted mittens, some slate pencils or a bag of jackstones, or if for a small boy, there might be tied to the toe of the stocking a cigar box with wheels fashioned from spools father had sawed and put on. And always, we were very happy with those small surprises, happier it seems to me than children of the present day with all their numerous gifts. Happiness does not come from the possession of a multitude of things, but comes from inside and consists of being satisfied with what you have.

We usually had snow at Christmas time and we wanted sleighing at that time, for it did not seem like Christmas without snow. Whether, over the years the seasons have changed, I could not judge, but I am sure we did have much more snow those winters when I was young.

Christmas Eve was usually the time when our Christmas trees with their programs were held. The first settlers brought with them the habits, customs and traditions of the land from which they came, whether it was from some foreign country or one of our eastern states. It so happened that in our vicinity there was a large settlement of German people and soon there were three German churches within easy driving distance 
from my father's home. One of these was even closer to us than our English-speaking church. The Germans were very particular about their Christmas tree. It had to be large; it had to be symmetrical and very beautiful. I have known them to drive long distances to obtain exactly the right type of tree they wanted.

In our church we were not so exacting about the tree. It need not be so perfect and never so large as theirs. But we always had a tree, and everybody far and near came to some one of these Christmas programs, usually in sleds and sleighs. The decorations of all trees consisted of long strings of popcorn and cranberries and we knew how to cut red and white tissue paper into lacelike festoons. And these, together with some big red apples and the candles, constituted the trimmings.

The program was the ordinary Sunday school typeChristmas songs, readings and exercises by classes. It was the custom for many years at our church for the parents to bring a small gift to be placed under the tree for each child and any other gifts could be brought for distribution. Hence quite often, the young men would bring gifts for their especial girl friends. And when the program was over, it would conclude with the singing of one of the Christmas songs and during the singing the young men as a lighting committee would come forward with their long tapers and light the candles on the tree.

At the conclusion of this, there would be a lot of stamping and sleigh bell ringing outside the door and Santa would come bounding in. He was always dressed in a bright red suit with white cotton trimmings and his medium circumference usually exceeded his altitude. When he had reached the platform and given his greetings to the children, the distribution of gifts began, and no child in the audience was omitted for if by any chance no gifts had been placed for one such, the Sunday School teachers and a committee had provided some little parcels as emergencies.

In connection with this part of our program, I have 
a story. I cannot vouch for its authenticity for it was told to me by another person. It seemed there was a certain young man who was engaged to be married and he wanted to give his betrothed something nice. In those days every house had a center table in the front room and on that table there was almost always one of those huge photograph albums. Some of them had elaborately decorated celluloid backs, some had plush, but all were highly ornamental and contained a collection of family portraits.

This young gentleman looked around and bought the nicest and most unique one he could find and he put it on the Christmas tree for his intended bride. She received the large package and could not restrain her curiosity, so she carefully removed the outer wrappings. About that time the presents having all been distributed, the superintendent announced that "If everyone now would please be quiet, the minister would come forward and deliver the closing prayer."

The minister began his prayer. But the young lady lifted the lid of the enclosing box and in so doing also lifted the lid of the album, thereby releasing the spring to a little tinkly music box that was concealed in a compartment at the back of the hinge. The minister finished his prayer to the tune of "Ha-Ha-Ha, you and me, Little brown jug don't I love thee."

\section{Family Circle A Happy One}

Christmas day was devoted largely to family reunions. In our family during my early childhood, the Christmas dinner was served at grandfather's house. Everybody, uncles, aunts and cousins came piling out of sleds, shouting "Merry Christmas" and "Christmas Gift." There seemed to be an idea that if you could say that before the other fellow did, he owed you the gift. But I never saw the gift delivered.

The men gathered around the old-fashioned heating stove in the front room and the women took possession of the kitchen. The children were allowed to go upstairs to play. The rooms upstairs were heated by the stovepipes which came up through the floor and by the 
registers surrounding those pipes, which permitted some heat to come from below. What fun we did have playing in grandmother's upstairs! I believe one-half the fun came from the "hush hushing" and the tiptoeing that was necessary to keep down the noise. In those days children were supposed to be seen and not heard. To become noisy or rude, or quarrelsome, would immediately bring aunty or mother to the head of the stairs with a stern rebuke. We were born into a world of law and order. First, there was the law of the home, then the laws of the community and of the school, and the laws of the country and of God. We were taught and expected to observe these.

Courtesy and consideration for the rights of others were a mark of good breeding and a failure therein was a reflection on our parents, and we were made to realize that. Being rude or impertinent to an older person or a failure in politeness meant a lecture from mother or a session with father in the woodshed. I am probably old-fashioned, but I cannot help feeling that if we had a little more of that sort of training in the home now, there would be much less trouble with juvenile delinquency today.

\section{Christmas Dances Enjoyable}

Dances and balls were very frequently held on Christmas night, or if not then, there certainly would be one during the week following and these were attended by many of the young people. Now, I would like to relate something of the way we dressed for these occasions. First, would be the long underwear clear down to the wrists and ankles, and for all grown girls there would be next the corset, then, two or three petticoats. The inner one was usually of some soft woolen material and over that a heavily ruffled white skirt or if not ruffled, there would be the second white skirt. One of these might have a waist to it, buttoned down the back for a girl, but an older woman would wear a corset cover instead. Then would come the dress made of the most lovely materials and would be of either wool or silk. None of these synthetic stuffs, but whether of wool, silk 
or satin, the fabrics were the genuine thing-all beautiful fabrics such as are not to be found in the markets today. The waist of the dress would be lined with a firmly woven cotton material and each seam would be stayed with a small whalebone stay that reached to the bust from the waist or below. This permitted no possibility of a wrinkle in that region. The skirt would be lined with a lighter weight cotton lining and the bottom would be padded with a buckram padded to about eight or ten inches in depth. Then the bottom would be finished with a close-woven hard twist wool braid about three-fourths to one inch wide, finely pleated, to take the wear where the skirt brushed the floor, as it did at the back.

I was born a little too late for the extreme lacing period, but we had an aunt who had laced as a young girl until her ribs lapped in front where there is supposed to be a space, and they remained lapped until she died. She lived to be near ninety years old, too. But even in my young-ladyhood, a small waist line was considered a mark of beauty. One of my girl friends told me that she never took her corset off except to bathe or change her underwear; that she slept in it and wore it constantly. And another confided in me that she always tied her corset strings together and threw them over the bedpost, then swung weight into them in order to attain the desired results.

I think it was owing to this sort of thing that fainting was so very common among the female population at that time. On nearly every occasion where there was a crowded room and the air became close, someone would faint or have to be taken from the room in a fainting condition. I think sometimes this was merely an excuse to get a little extra attention from her escort. But however that might be, fainting was very very common. Being frail, delicate, fragile and helpless were considered female attractions in those days.

I remember during my stay at that academy, two of my girl friends were reading a novel and in that novel the heroine was described as being "pale, wan and in- 
teresting" and so they decided that they too wanted to be pale, wan and interesting and in order to obtain the desired condition, they stayed awake all night the night before a certain occasion they were attending. They were pale and wan all right, but I doubt about the interesting part.

Another girl confided in me that when she had a beautiful costume to wear, she always contrived to be a little late at the affair attended and before she entered the room, she would say "prunes and prisms" because it left her lips in so attractive a position.

\section{The Doctor Gave Relief}

In connection with that lacing period, I want to relate a story. This one I can vouch for its truth, for it happened among the crowd of young people with whom I ran around when I was a young lady. There was a girl of my own age whose name was Alta, and she was planning to go to the Christmas dance. An aunt of hers had come to spend the holidays with them and this aunt had a very beautiful dress. Since she and Alta were in almost every respect the same size, Alta wanted to wear her aunt's dress. The one exception as to size was that the aunt being of an earlier generation had cultivated a smaller waist line. Consent being given to the proposition, Alta began in the forenoon tightening her corset and at intervals during the day repeated the process until by the time for the dance, she could put on the dress and she wore it to the dance. The evening progressed and Alta was on the floor dancing and she fainted. They picked her up and laid her on the seats that ran around the hall. The girls got out their smelling salts and put wet cloths on her face, but she did not revive. She was down and out. The boys went outside and got snow and put in her face all to no avail. So they became alarmed and went down the street, got the doctor out of bed and brought him up to the hall. He looked at her and told them to stand back away from her; rolled her over, unbuttoned the dress and took out his jack knife. They told me they could hear the popping of those corset strings all over 
the hall. And poor Alta had to put on her coat and her escort had to take her home. You see, I was not at the dance because my parents did not allow me to attend dances, but I heard all about it the next day.

Also, at Christmas time there were numerous parties. These were held in the homes and all the young people in the vicinity would be invited. At these parties, we played games-"Blind man's Buff," "Button-button, who has the button." Then there were the singing games which were so popular all during my girlhood- "The Miller in the Mill," "Captain Jenks," "Weavely Wheat" and many others. I did not reveal the fact to my parents that I knew and frequently danced the entire "Virginia Reel" to the tune of "Weavely Wheat." Singing games were permissable. Refreshments at these parties were very simple, apples or popcorn balls, perhaps occasionally doughnuts and cider. If the party was at our house, it usually ended in a taffy pull. My father was the community sorghum maker and we always had a barrel or two of sorghum in our summer kitchen.

When the games were about over, mother or the chaperon of the group would go to the kitchen and put the molasses on to boil. When it reached the desired consistency, it would be poured on buttered plates and set aside to cool. All the guests would be lined up with the washbowl and towels set conveniently for use; all hands would be washed and buttered and each person would be given a wad of taffy. It really was a lot of fun to pull taffy. The longer it was pulled and the cooler it got, the lighter it became in color and the stiffer. It may have been the frequent buttering of hands that improved the flavor, but the finished product was really very good. When it was very creamy in color and stiff, we frequently rolled each wad in nutmeats, wrapped it in buttered papers, and the owner of it was given their portion to take home with them. The one other thing I now miss very much is the bells-the Christmas bells which rang out a joyous peal of the anniversary of the birth of Christ. Every church 
had a bell at that time and the German church especially had a very large beautifully toned bell that could be heard for miles. Then there were the sleigh bells. Step outside then and you certainly would hear, perhaps from several directions, the tinkle of sleigh bells. The big strands reached clear around the horses. Then there were the small silvery sounding ones that were fastened to the driving harnesses. And I do not feel that Poe was insane when he wrote "The bells, bells, bells! The rhyming and the chiming of the bells."

\section{A Memorial to Frank Pellett}

A five-acre tract of woods, including much of Iowa's plant and flower wildlife, located two miles northeast of Atlantic, Iowa, has been dedicated to the late Frank C. Pellett, internationally known naturalist and author.

The memorial site is in the Pellett Gardens operated by Melvin Pellett, son of the naturalist. The memorial ceremonies including the establishment of two plaques mounted on native stone at the entrance of the woods.

In 1947, Pellett received an award from the National Council of State Garden Clubs for horticultural achievement and an award and medal from the Iowa State Horticultural society.

The memorial to Pellett is being sponsored by the Iowa State Horticultural Society and affiliated societies. His biography appears in the AnNals, Vol. XXXI, (1951), No. 2, p. 156. 
Copyright of Annals of Iowa is the property of State of Iowa, by \& through the State Historical Society of Iowa and its content may not be copied or emailed to multiple sites or posted to a listserv without the copyright holder's express written permission. However, users may print, download, or email articles for individual use. 